\title{
PENJATUHAN HUKUMAN PIDANA MATI TERHADAP TINDAK PIDANA NARKOTIKA
}

\author{
Novrianza, Mitro Subroto \\ Politeknik Ilmu Pemasyarakatan \\ Email:novrianza17@gmail.com,mitro.suroto@gmail.com
}

\begin{abstract}
The death penalty can be described as a form of punishment regulated in law number 35 of 2009 which regulates the abuse of narcotics crimes. This death penalty legislation has caused various kinds of conflicts because the death penalty is not in accordance with the 1945 constitution which is contrary to human rights and many also argue that the death penalty must be implemented in order to have a deterrent effect on the perpetrators of narcotics abuse. This form of death penalty is the most cruel and sadistic form of punishment because this punishment kills a person's life. this type of research is done by means of a qualitative approach. The purpose of this study is to find out the imposition of the death penalty for narcotics crimes. Results showed if the application of the death penalty can only be against acts of criminal acts were limits of humanity, threatening the lives of many people, destructive to human life, and may damage the nation's economy. The imposition of the death penalty is not against human rights. along pejustified afirstasan human rights
\end{abstract}

Keywords: narcotics crime, human rights, the death penalty

\begin{abstract}
Abstrak
Pidana mati dapat digambarkan sebagai bentuk salah satu hukuman yang diatur dalam perundang-undangan nomor 35 tahun 2009 yang mengatur penyalahgunaan tindak pidana narkotika. Perundang-undangan pidana mati ini menimbulkan berbagai macam konflik, dikarenakan bahwa hukuman mati tidak sesuai dengan undang-undang dasar 1945 yang bertentangan dengan hak asasi manusia dan banyak juga yang berpendapat bahwa hukuman mati harus dilaksanakan agar menimbulkan efek jera kepada para pelaku penyalahgunaan narkotika. Bentuk hukuman mati ini merupakan sebagai bentuk hukuman yang paling kejam dan sadis dikarenakan hukuman ini menghilangkan nyawa seseorang. Jenis penelitian ini dilakukan dengan cara pendekatan kualitatif. Tujuan dari penelitian ini guna agar mengetahui penjatuhan hukuman pidana mati terhadap tindak pidana narkotika. Hasil penelitian menunjukkan jika penerapan hukuman mati cuma bisa dilakukan terhadap perbuatan tindakan pemidanaan
\end{abstract}


yang meIampaui batas peri kemanusiaan, mengancam kehidupan banyak orang, merusak tatanan kehidupan manusia, dan dapat merusak perekonomian bangsa. Penjatuhan tindak pidana mati tidak bertentangan dengan HAM, bisa dibenarkan sepanjang pelaksanaannya sebagai alasan membela HAM.

Kata Kunci : tindak pidana narkotika, hak asasi manusia, hukuman mati

Diterima: 12-10-2021_Direvisi: 13-11-2021_ Diterbitkan: 20-11-2021

\section{Pendahuluan}

Penjatuhan bentuk pemidaan hukuman mati terhadap pelaku tindak pidana penyaIahgunaan narkotika dan juga efek jera yang di rasakan dari vonis pemidanaan mati ini oleh pengadilan kepada tersangka atau pelaku jenis kejahatan perbuatan tersebut diIaksanakan karena kerugian dan penderitaan yang di alami oleh korban dari adanya barang terlarang tersebut biasanya kerugian berupa material dan non material. Korban biasanya sebagian besar adalah remaja. Penjatuhan pemidanaan mati ini sangat mustahil akan hilangnya berbagai jenis kejahatan di dunia, dari adanya hukuman mati ini setidaknya akan berdampak pada kesadaran di depan hukum terhadap korban dari kejahatan narkotika ini. Untuk mengurangi bentuk kejahatan ini pemerintah mengeluarkan peraturan perundang-undangan yang membahas dan mengatur tentang tindak pidana narkotika yang sekarang dilaksanakan dan di terapkan yaitu undang-undang nomor 35 tahun 2009 membahas tentang tindak pidana narkotika (Satriana, Purwoto, \& Astuti, 2018). Diharapkan agar menimbulkan efek jera bagi para pelaku terpidana atau orang yang ini melakukan tindakan tersebut.

Pertumbuhan kejahatan terhadap para penyalahgunaan narkotika ini dari waktu ke waktu yang makin Lama makin meningkat. Apalagi telah banyak permasalahan yang terungkap. Tingkatan peredaran narkoba telah memasuki ke bermacam tingkat, tidak cuma pada perkotaan saja melainkan telah terletak di dalam pedesaan. Kasus narkoba di Indonesia yang terus menjadi gempar teruji dengan bertambahnya jumIah pecandu secara yang bersamaan terungkapnya setiap permasalahan yang terjadi akibat dari adanya tindak kejahatan ini, yang terus jadi bervariasi serta terus menjadi tersebar banyak sindikat perdagangan narkoba. Indonesia merupakan bangsa yang menerapkan hukuman yang berdauIat. Di tiap macam aksi pemerintah di lapangan baik pengaturan maupun peIayanan wajib yang di dasarkan pada perundang-undangan ( $\mathrm{Lu}, 2015)$.

Permasalahan narkoba adalah salah satu kejahatan Luar biasa (extra ordinary crime) yang di sebabkan dampak negatif dari permasalahan ini besar sekali, yang akan mengecam seluruh orang, baik kanak-kanak, remaja ataupun orang tua apalagi mengganggu satu generasi serta masa depan dari sesuatu negeri. Untuk kasus ekstrim atau perjahatan Luar biasa dari hukuman mati semestinya dilakukan dimana untuk memberikan efek jera dengan dilakukannya pencegahan, pemberantasan, dan penegakan hukum secara adil sesuai dengan penerapan hukum yang berlaku untuk masa depan yang Lebih baik, positif, dan bersih dari narkotika. Maka dalam penelitian ini peneliti bertujuan untuk memberikan penjeIasan mengenai kebijakan hukum dalam bentuk pelaksanaan 
hukuman mati yang terjadi di Indonesia berdasarkan ketentuan peraturan perundangundangan yang berlaku (Anjari, 2015).

Berdasarkan bentuk uraian latar belakang tersebut, maka penulis akan menemukan perumusan masalah memfokuskan tentang: bagaimanakah penerapan sanksi hukuman mati bagi para narapidana narkotika? Faktor apa sajakah yang menghambat dalam penerapan hukuman mati bagi para narapidana narkotika?

\section{Metode Penelitian}

Jenis penelitian ini menggunakan pendekatan kualitatif. Penelitian kualitatif adalah bentuk jenis penelitian dengan mengumpulkan data yang digunakan sebagai bahan data dan tindak memakai angka untuk objek penelitiannya. Data yang diambil yaitu data kualitatif. Dalam memperoleh data yang akan di ambil yaitu di peroleh dari beberapa sumber seperti jurnal, buku, dan sumber-sumber lainya.

\section{Hasil dan Pembahasan}

\section{Penerapan Sanksi Hukuman Mati bagi Para Narapidana Narkotika}

Membahas hukuman mati, Indonesia merupakan negeri yang masih mempraktikkan hukuman mati. Hukuman mati adalah bentuk pidana pokok yang tercantum didalam KUHP pasal 10. Penjatuhan pada hukuman ini tidak sedikit di protes oleh para organisasi yang menyangkut dengan hak asasi manusia. Mereka berpandangan kaIau penjatuhan hukuman mati sudah meIanggar hak asasi manusia seorang adalah hak buat hidup. Mempertentangkan bentuk hukuman mati sebagai tidak memandang dengan hak asasi manusia, dengan ini perIu di pahami mengenai tentang peIanggaran terhadap hak asasi manusia. Penjatuhan pemidanaan hukuman mati kepada pengedar narkoba secara tertulis telah sesuai dengan peraturan yang di atur di dalam perundang-undangan nomor 35 tahun 2009 yang membahas tentang narkotika (Nita, 2014)

Lebih penting persyaratan dengan keadaan yang sesuai di terapkan hukuman mati dan bahkan bila meIanggar hukum hak asasi manusia, tetapi perbuatan tersebut tidak dianggap sebagai tindakan ilegal. Apalagi mengenai dalam hal pelanggaran hak asasi manusia apalagi jika yang dilakukan pengedar narkoba memiliki cangkupan pengedar narkotika pengaruh yang luas. Tidak sedikit pecandu narkoba sembuh tetapi hanya sementara dan kembali lagi menjadi kambuh. Dengan ini adanya efek kecanduan dan tidak memiliki uang merupakan faktor dari dampak timbulnya mendorong pecandu narkoba dapat berbuat jahat. Pengedar narkoba dapat disimpulkan bahwa telah merusak generasi penurus bangsa karena dengan adanya narkoba tersebut hak asasi manusia pada remaja akan hilang (Samadi, 2015).

Belum adanya pembuktian dengan hukuman mati dapat dibandingkan dengan jenis hukuman lain akan menghasilkan efek jera dan efektif dalam penghukuman. Bentuk kriminalitas berkaitan erat sebagai masalah kesejahteraan sosial dan kemiskinan. Dukungan kepada hukuman mati dilandasarkan pada pendapat bahwa hukuman mati harus dijatuhkan termasuk mengancam pelanggar. Kesadaran masyarakat dapat berpikir ketika mereka ingin melakukan kejahatan. Jika pemenjaraan pelaku kriminal tidak akan 
mencegah hukuman mati yang ditujukan untuk mereka tidak bisa dilakukan kembali, karena dia dijatuhi hukuman mati, yang pada dasarnya untuk menyelamatkan kehidupan (Permaqi, n.d.). Keberadaan hukuman pidana mati terhadap pelaku tindak penyalahgunaan narkotika pada nyatanya merupakan masih menjadi masalah antara yang setuju dengan yang tidak terhadap adanya hukuman mati ini, namun kenyataanya sanksi pemidanaan hukuman mati selain masih aktif di dalam peraturann hukum pemidanaan positif, di dalam KUHP juga masih di atur mengenai itu. Dari jaman dulu pidana mati ini dikenakan kepada tindak kejahatan berat. Dikarenakan berdasarkan atas pembalasan kepada perbuatan yang kejam, tujuan dari penjatuhan pidana mati ini mereka akan takut melakukan tindakan kejam yang nantinya akan berdampak kepada mereka dijatuhi hukuman pidana mati. Pada jaman dahuIu hukuman mati ini dilaksanakan dan diterapkan di depan umum, maka yang menjadi dasar utamanya dari adanya penjatuhan pidana mati ini (Hidayat, 2013).

Selain itu hukuman pidana mati ini masih wajar dilaksanakan kepada para pelaku atau pengedar tindak kehajatan narkotika. Seperti yang diketahui kejahatan tindakan narkotika ini sebagai salah satu bentuk tindakan kejahatan terberat dan sadis. Untuk pemberian sanksi penghukuman yang berat dan sadis ini harus di laksanakan dan di praktikan kepada pelaku tindakan kejahatan tersebut.

\section{Faktor yang Menyebabkan Penjatuhan Penerapan Hukuman Mati bagi Para Narapidana Narkotika}

Hukuman mati adalah hukuman yang terberat dalam jajaran hukum pemidanaan. Penyalahgunaan narkotika inilah terancam dengan pidana. Sanksi pidana dalam perundang-undangan narkotika ini berbagai macam sesuai dengan tindak pidana dilakukan, melainkan dikarenakan tindak kejahatan jenis narkotika itu merupakan sebagai jenis tindak kejahatan extra ordinary crime. Pemberian pemidanaan hukuman mati kepada pelaku tindak kejahatan pidana narkotika tersebut dikarenakan oleh berbagai faktor. Dalam undang-undang nomor 35 tahun 2009 mengenai narkotika telah jelaskan sebagai tidak lansung faktor-faktor apa saja yang mampu terjadinya penjatuhan pidana mati (Fari \& Dewi, 2021).

Faktor-faktor yang dapat terjadinya penjatuhan hukuman pidana mati kepada pelaku tindak kejahatan pidana narkotika adalah sebagai berikut yaitu: (Pratama , Andra, 2015)

1) Pelaku yakni dikategorikan kedalam pengedar narkotika golongan I dan II yang dilakukan secara sistematis.

2) Pelaku yakni miIiki jenis dari narkotika golongan I dan II, sebesar 300 gram atau lebih.

3) Pelaku yakni sebagai pengolah atau orang yang membuat goIongan I dan II.

4) Pelaku sebagai pembawa jenis narkotika golongan I dan II.

5) Pelaku sebagai pengantar jenis narkotika golongan I dan II.

6) Pelaku terbukti keterlibatan dalam sindikat perdagangan narkotika yang besar.

Maka dari faktor tersebut pemberian penjatuhan pidana mati kepada pelaku tindak kejahatan narkotika diberikan kepada pelaku tindak kejahatan pidana narkotika dan 
ditujukan cuma untuk para pelaku yang tergolong ke dalam pemakai narkotika khususnya golongan I dan II yang sebagai pemiIik, pengedar, pengelola, yang membawa dan yang mengantar terutama jika pelaku tersebut terlibat kepada jaringan pengedar yang besar (Amrani \& Wati, 2017). Yang seperti kita ketahui tindak kejahatan narkotika merupakan suatu bentuk tindak kejahatan yang tergolong ke dalam extra ornidary crime yang memiliki dampak negatif yang sangat besar bagi keberlangsungan bangsa. Pidana mati ini adalah sanksi yang terberat bagi tindak pelaku narkotika karena dengan ini pemberian hukuman mati kepada para pelaku diharapkan akan menimbulkan efek jera. Hal ini sebanding dengan akibat yang dari mereka perbuat. Pada sistem hukum eksekusi mati ini dilaksanakan setelah keputusan pengadilan yang berkekuatan hukum tetap dan terpidana mati ini dapat mengajukan grasi kepada bapak presiden. Pelaksanaannya eksekusi ini dilaksanakan atas persetujuan presiden (Handika \& Dermawan, 2010).

\section{Kesimpulan}

Penerapan hukuman mati cuma bisa dilakukan terhadap perbuatan tindakan pemidanaan yang meIampaui batas peri kemanusiaan, mengancam kehidupan banyak orang, merusak tatanan kehidupan manusia, dan dapat merusak perekonomian bangsa. Penjatuhan tindak pidana mati tidak bertentangan dengan HAM, bisa dibenarkan sepanjang pelaksanaannya sebagai alasan membela HAM.

Dalam penerapan hukuman mati, faktor pendorong dan faktor penghambat yang terjadi di Indonesia ditinjau dari aspek perundang-undangan. Dijelaskan dalam undangundang narkotika mengenai dasar hukum dalam menerapkan hukuman mati dan pada perundang-undangan nomor 5 tahun 2010 mengenai pergantian atas UU nomor 22 tahun 2002 di Indonesia juga memberikan grasi kepada terpidana. Pada aspek sosial masih banyaknya pro dan kontra yang terjadi di Indonesia. Demi menjaga kehidupan generasi bangsa dan negara, setiap orang bebas untuk berpendapat terhadap penerapan hukuman mati yang berlangsung di Indonesia dan pendapat mereka dapat memberikan contoh positif bagi masa depan. 


\section{BIBLIOGRAFI}

Amrani, Hanafi, \& Wati, Ayu Widya. (2017). Urgensi Penjatuhan Pidana Mati Terhadap Pelaku Tindak Pidana Narkotika Dan Relevansinya Dalam Perspektif Hukum Dan Hak Asasi Manusia. 1-61. Google Scholar

Anjari, Warih. (2015). Penjatuhan Pidana Mati di Indonesia dalam Perspektif Hak Asasi Manusia. Jurnal Widya Yustisia, 1(2), 107-115. Google Scholar

Fari, Fuad Alghi, \& Dewi, Susi Fitria. (2021). Faktor penyebab terjadinya tindak pidana kejahatan narkotika. 4(1), 431-443. Google Scholar

Handika, Anda, \& Dermawan, Putra. (2010). Kata Kunci: Grasi, Terpidana dan Narkotika. 1-14. Google Scholar

Hidayat, Syamsul. (2013). the Controversy of Applying the Death Sentence for Criminal Acts Related To Drugs. 500-522. Google Scholar

Lu, Sudirman. (2015). Penerapan hukuman mati tindak pidana narkotika di indonesia. (2), 59-74. Google Scholar

Nita, Ariyulinda. (2014). RechtsVinding Online Hukuman mati narapidana narkoba dan hak asasi manusia. Google Scholar

Permaqi, Farhan. (n.d.). Hukuman mati pelaku tindak pidana narkotika dalam perspektif hukum dan hak asasi manusia (Dalam tinjauan yuridis normatif) (The death penalty for preparators of the narcotics crime on law and human rights perspective (In a juridical normative review)). Google Scholar

Pratama, Andra, Zulfi. (2015). Dasar hukum dan faktor-faktor yang dapat menyebabkan penjatuhan pidana mati terhadap pelaku tindak pidana narkotika menurut sistem hukum di indonesia. Google Scholar

Samadi, Yessy Paramita. (2015). Lex Crimen. Lex Crimen, Vol. IV(8), 94-102. Google Scholar

Satriana, Muhammad Ilham, Purwoto, Purwoto, \& Astuti, A. M. (2018). Tinjauan Pelaksanaan Eksekusi Pidana Mati Terhadap Pelaku Tindak Pidana Narkotika Di Indonesia. Universitas Diponegoro. Google Scholar

First publication right:

Jurnal Syntax Fusion: Jurnal Nasional Indonesia

This article is licensed under:

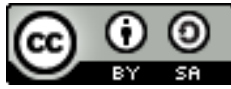

